\title{
Estimate of housing and population in landslide risk areas in California (USA) and coastal São Paulo (Brazil)
}

\author{
Estimativa de residências e população em áreas de risco a \\ deslizamentos na costa da Califórnia (EUA) e São Paulo (Brasil)
}

Estimación de viviendas y población en áreas de riesgo de deslizamientos en California (EE. UU.) Y la costa de São Paulo (Brasil)

\author{
Saulo de Oliveira-Folharini ${ }^{1}$ \\ University of Campinas, Brazil \\ Regina Célia de-Oliveira ${ }^{2}$ \\ University of Campinas, Brazil \\ J. Christopher-Brown ${ }^{3}$ \\ University of Kansas, USA
}

\begin{abstract}
The States of California and São Paulo are associated historically with natural disasters including forest fires and high precipitation, respectively. These events end up causing numerous deaths and financial and social losses. Even in the face of loss of life, and in some cases despite the lack of urban planning, populations still choose to live in places of risk, valuing them for scenic beauty or exclusivity. The aim of this study is to estimate the amount of people and housing in landslide risk areas in California and the São Paulo state coastal zone, using satellite image classification, Aster DEM and census data. The results indicate that in California, from 2000 to 2016, the urban area increased $1.83 \%$ and São Paulo increased $14.92 \%$, indicating that occupation in the landslide

1 PhD Candidate in Geography, University of Campinas, Brazil, sfolharini@gmail.com

2 Dra. Professor of Geography Department, University of Campinas, Brazil, reginacoliveira@ige.unicamp.br

3 Dr. Professor of Environmental Studies Program, the University of Kansas, USA. jcbrown2@ku.edu

Este artículo corresponde a la ponencia presentada en el 35th Conference of Latin American Geographers realizada en San José, Costa Rica del 20 al 22 de mayo del 2018.
\end{abstract}


risk area in California was already consolidated, and in São Paulo there was a large increase in risk because the increased population. Compared to California, São Paulo's population and housing is a much greater landslide risk.

Keywords: Landslide, Risk, Satellite Image, Estimate, Urban Area.

\section{Resumo}

Os estados da Califórnia e São Paulo têm histórico de deslizamentos associados a eventos naturais, respectivamente, extensos incêndios florestais e alta precipitação. Estes eventos naturais somados resultam em numerosas perdas de vidas, financeiras e sociais. O cenário de perda de vidas é resultado basicamente da escolha da população em viver em áreas de risco, com grande beleza cênica, exclusividade ou falta de planejamento urbano. O objetivo deste estudo é estimar o número de pessoas e residências em áreas de risco a deslizamentos nas costas da Califórnia e São Paulo, usando classificação de imagens de satélite, MDE Aster e dados censitários. O resultado da classificação de uso e cobertura indica que na Califórnia o período de 2000 a 2016 a área urbana aumentou $1.83 \%$ e São Paulo aumento $14.92 \%$, indicando que a ocupação de áreas de risco a deslizamentos na Califórnia já foi consolidada e São Paulo ocorreu aumento do risco porque mais pessoas estão vivendo nessas áreas. Já sobre a estimativa de população e residências vivendo em áreas de risco a deslizamento, São Paulo têm mais pessoas e residências vivendo nestas áreas comparativamente à Califórnia.

Palavras-chave: Deslizamentos, Risco, Imagens de Satélite, Estimativa, Área Urbana.

\section{Resumen}

Los estados de California y São Paulo tienen antecedentes de deslizamientos asociados a eventos naturales, respectivamente, extensos incendios forestales y alta precipitación. Estos acontecimientos naturales sumados resultan en numerosas pérdidas de vidas, financieras y sociales. El escenario de pérdida de vidas es resultado básicamente de la elección de la población en vivir en áreas de riesgo, con gran belleza escénica, exclusividad o falta de planificación urbana. El objetivo de este estudio es estimar el número de personas y residencias en áreas de riesgo a deslizamientos en las costas de California y São Paulo, usando clasificación de imágenes de satélite, MDE Aster y datos censales. El resultado de la clasificación de uso y cobertura indica que en California en el período de 2000 a 2016 el área urbana aumentó el 1.83\% y en São Paulo aumentó el 14.92\%, indicando que la ocupación de áreas de riesgo a deslizamientos en California ya fue consolidada y en São Paulo ocurrió un aumento del riesgo porque más personas están viviendo en esas áreas. En cuanto a la estimación de residencias y población viviendo en áreas de riesgo a deslizamiento, São Paulo tiene más residencias y personas viviendo en estas áreas en comparación con la región California.

Palabras clave: deslizamiento de tierra, riesgo, imagen satelital, estimación, área urbana.

\section{Introduction}

The disaster events, such as hurricanes, tsunamis, earthquakes, and mass wasting (landslide), are initiated by natural processes modified by man, causing human and material damage to the population occupying an affected area. For Smith (2004, p.12) disasters “... are social phenomena that occur when a community suffers exceptional, non-routine, levels of 
Saulo de Oliveira-Folharini, Regina Célia de-Oliveira. Estimate of housing and population in landslide risk areas in California (USA) and coastal São Paulo (Brazil)

disruption and loss". Due to the concentration of people in urban centers that historically have developed in areas vulnerable to natural events, such as the hillsides and coastal plains, the number of people vulnerable to these events is increasing. This concentration of people is related to typical socioeconomic development processes that focus better economic and social opportunities in concentrated geographic territories. According to Bonachea et al. (2010), the significant increase in the frequency of disasters in the world is related to the advance of human occupation, mainly since the 1980s. This study addressed the increase of landslides on the surface due to changes in human activities, reduced resilience of the surface layer, and increased surface flow. This process increases geomorphological processes such as landslides, which in turn are affected by the number of people in a region and its economy and level of technological development. The study employed different population indicators such as GDP and energy consumption to characterize the transformations on the surface caused by man that can result in geomorphological processes.

Social inequality also plays a role in increasing risk of landslides. As people concentrate in large cities with better employment and income opportunities, together with the predominant model of the consumer society, social inequality increases. In turn, people may be forced to live in high risk areas, as demonstrated in Robbins (2012, p. 112):

if, for example, changing land prices drive poor people - with relatively little latitude of choice for house construction - into building houses on steep hillsides, immediate erosion may not be visible or evident, but the risk of catastrophe during an abnormal rain event is definitely increased.

Understanding the natural conditions and socioeconomic issues that lead to increased vulnerability is critical to planning land occupation and mitigating measures for such events. These events are continually influenced by systems of political and economic power (Bonachea et al., 2010; Oliver-Smith et al., 2016; Robbins, 2012).

The aim of this study is to estimate the amount of people and housing within areas with slope above $30^{\circ}$ in the following counties: Orange, Los Angeles and Ventura counties (California/USA) and Bertioga, Guarujá, Santos, São Vicente, Cubatão, Praia Grande, Mongaguá, Itanhaém, 
Saulo de Oliveira-Folharini, Regina Célia de-Oliveira. Estimativa de residências e população em áreas de risco a deslizamentos na costa da Califórnia (EUA) e São Paulo (Brasil)

Peruíbe, São Sebastião, Ilhabela, Caraguatatuba and Ubatuba (São Paulo/ Brazil) using satellite image classification, Aster DEM and census data.

\section{Study areas}

The states of California and São Paulo (figure 1) have a history of landslides that affect the population.
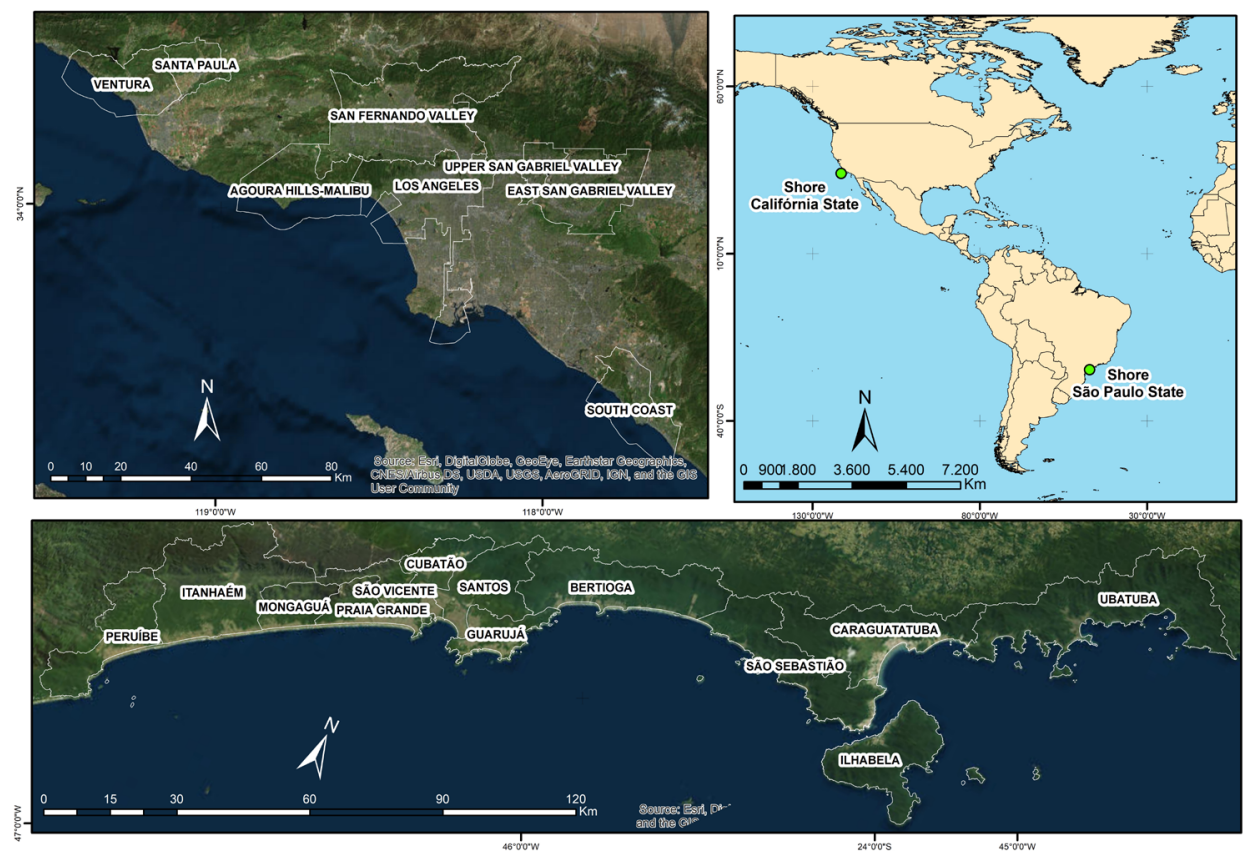

Figure 1: Study Areas. Organized by the author.

In coastal California in the 20th century, agricultural production and oil exploration became the two main products responsible for economic growth of the state that had a GDP of US\$ 2.4 billion in 2015, according to the IMF (Miller and Hyslop, 2000).

In coastal São Paulo, large populations came to center around the installation of petroleum, steel and chemical industries, especially in the region of Cubatão. There was also a high level of real estate speculation resulting from the implementation of industries in the Baixada Santista, and with the scenic beauty of São Paulo's North Coast, populations also settled in areas vulnerable to risks, such as mangroves, sandbacks and high slopes (Moraes, 2007). 
Saulo de Oliveira-Folharini, Regina Célia de-Oliveira. Estimate of housing and population in landslide risk areas in California (USA) and coastal São Paulo (Brazil)

These counties were selected due to their common history of landslides, studies to Goldbeg (2006) and Highland; Bobrowsky (2008) in California and Ab'Saber (1987), Cruz (1974) and Tatizana et al. (1987) in São Paulo coastal report the susceptibility the landslides in areas and because they contain areas with more than $30^{\circ}$ slopes, a common characteristic used in studies in both areas to measure susceptibility to landslides (Bitar, Freitas and Ferreira, 2012; Dai \& Lee, 2002; Wills, Perez and Gutierrez, 2011).

\section{Methodology}

This research was divided into three steps: 1) Slope calculation and interpolation (IDW) to determine the concentration of slopes above $30^{\circ}$; 2) Satellite image classification to determine expansion of urban area; 3 ) Estimation of population and housing in slopes above $30^{\circ}$ (figure 2):

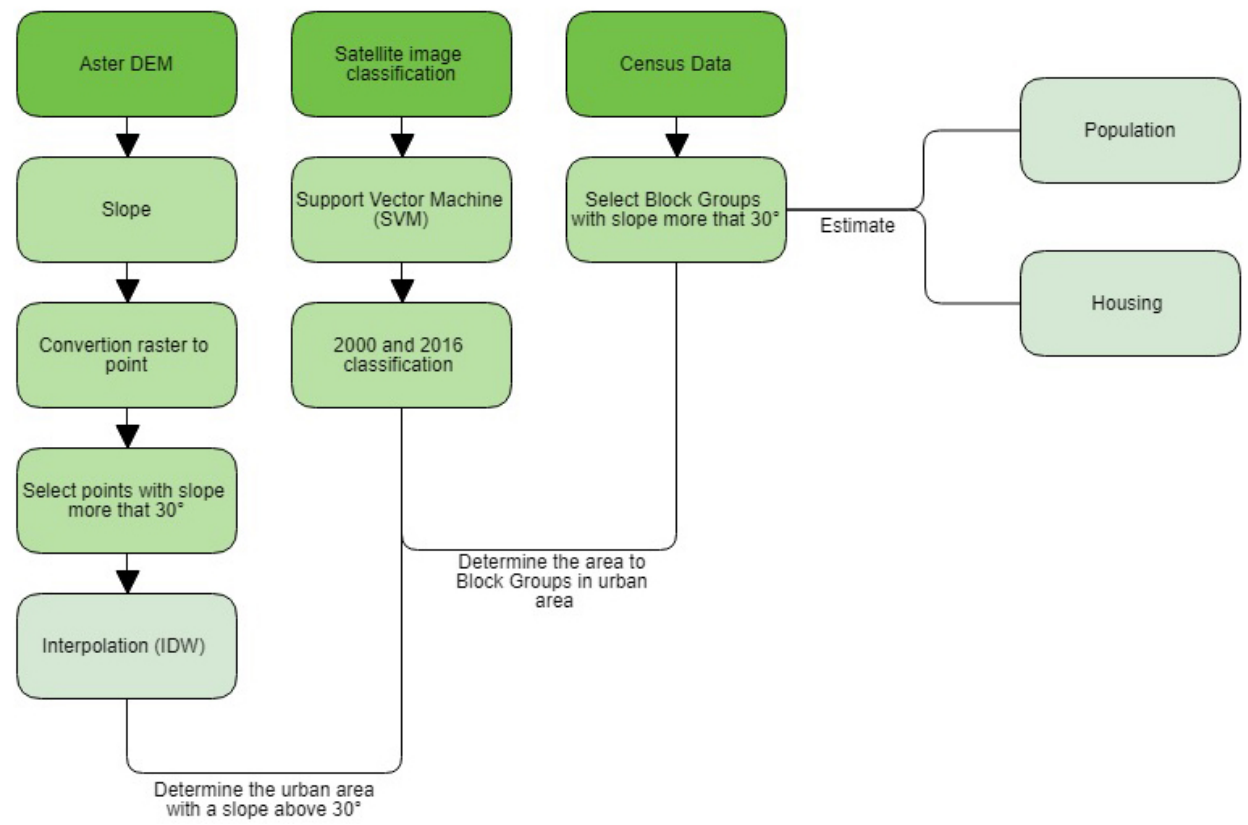

Figure 2: Steps of research. Organized by the author

To calculate the slope concentration not suitable for occupation, we followed Dai and Lee (2002), Wills, Perez and Gutierrez (2011) and Bittar, Freitas, Ferreira (2012) and who all determined occupancy limits 
according to slope degree. The studies considered $30^{\circ}$ to $45^{\circ}$ of slope as areas where occupation should be avoided; above $45^{\circ}$ areas should not be occupied. This numbers were based on geological, geomorphological, pedological, climate and land use/land cover change maps integrated with additional information about material resistance, water infiltration capacity and mobilization of the constituent material of the slope. In addition, we identified temporal change in land cover and how that change accelerates the landslides. First, the Aster DEM raster was processed in ArcGIS®, calculating the slope degree; next, the slope raster was converted to a point shapefile and points above $30^{\circ}$ were selected. These selected points were interpolated with the toolbox IDW (Inverse Distance Weighting).

The second step involved the the classification of images to analyze changes in land use and land cover in different contexts, using the Support Vector Machine (SVM), which, considering a set of samples collected, optimizes the classification of optimal limits between classes (Cortes \& Vapnik, 1995; Huang, Davis and Townshend, 2002). According to the work of Steinwart and Christmann (2008), this algorithm has three characteristics that make it superior to others: 1) With a small number of samples the algorithms have good learning results, 2) It has a high level of rubstness, with $n$ types of violations and diversities of model, 3) Compared to other models it is more computationally efficient. In this step LANDSAT 5 (TM) and 8 (OLI) images of the following dates were used (table I):

Table I: Image date

\begin{tabular}{|c|c|c|c|c|c|}
\hline \multicolumn{3}{|c|}{ California } & \multicolumn{3}{c|}{ São Paulo } \\
\hline \multicolumn{2}{|c|}{ Date } & Path/Row & \multicolumn{2}{c|}{ Date } & Path/Row \\
\hline $2000-05-18$ & $2016-09-03$ & $040 / 037$ & $2000-01-10$ & $2016-08-17$ & $218 / 76$ \\
\hline $2000-08-13$ & $2016-09-26$ & $041 / 036$ & $2000-01-10$ & $2016-08-17$ & $218 / 77$ \\
\hline $2000-08-20$ & $2016-03-09$ & $042 / 036$ & $2000-06-25$ & $2016-07-07$ & $219 / 76$ \\
\hline & & & $1999-12-16$ & $2016-07-07$ & $219 / 77$ \\
\hline & & & $2000-05-31$ & $2016-06-12$ & $220 / 77$ \\
\hline
\end{tabular}

These images were acquired from the US Geological Survey (USGS) database and processed in the ENVI software. After download and pre-processing, images were stacked and we clipped the data to the study area. We 
then classified the images into the following classes: agriculture, exposed soil, urban area, vegetation and water.

After the classification, we calculated the Kappa index: the 2000 California classification had a Kappa Index of 0.897, and the 2016 classification had a Kappa Index of 0.871. The 2000 São Paulo classification had a Kappa Index of 0.840 and the 2016 image had a Kappa Index of 0.858. According Galparso ans Fernández (2001) Kappa index value greater than 0.81 are considered excellent. We then extracted the urban area and correlated it with IDW results, resulting in the urban area with slopes above $30^{\circ}$.

Step three involved selecting the block groups in the census data intersecting with the urban area with slope above $30^{\circ}$ and then estimating the population and housing in the block groups living in the urban area identified as inappropriate for occupation.

\section{Results}

The great extension of the coastal plain favored the expansion of the urban occupation of the Los Angeles metropolitan area until it reached the limits of mountainous areas. This first occurred on the coastline of Ventura and Orange counties (figure 3) where the construction of Highway 01 facilitated the flow of people and their occupation of areas along the highway. Second, occupation occurred in the areas of Hollywood and Beverly Hills (figure 4) in Los Angeles county, and third in the Mountains of San Gabriel in Upper San Gabriel Valley and East San Gabriel Valley counties (figure 5). In these places the expansion of the urban area occurred along with the increase of landslide risk, made even worse by periods of intense rains that occur along the American west coast (Biasutti, Seager and Kirschbaum, 2016). 

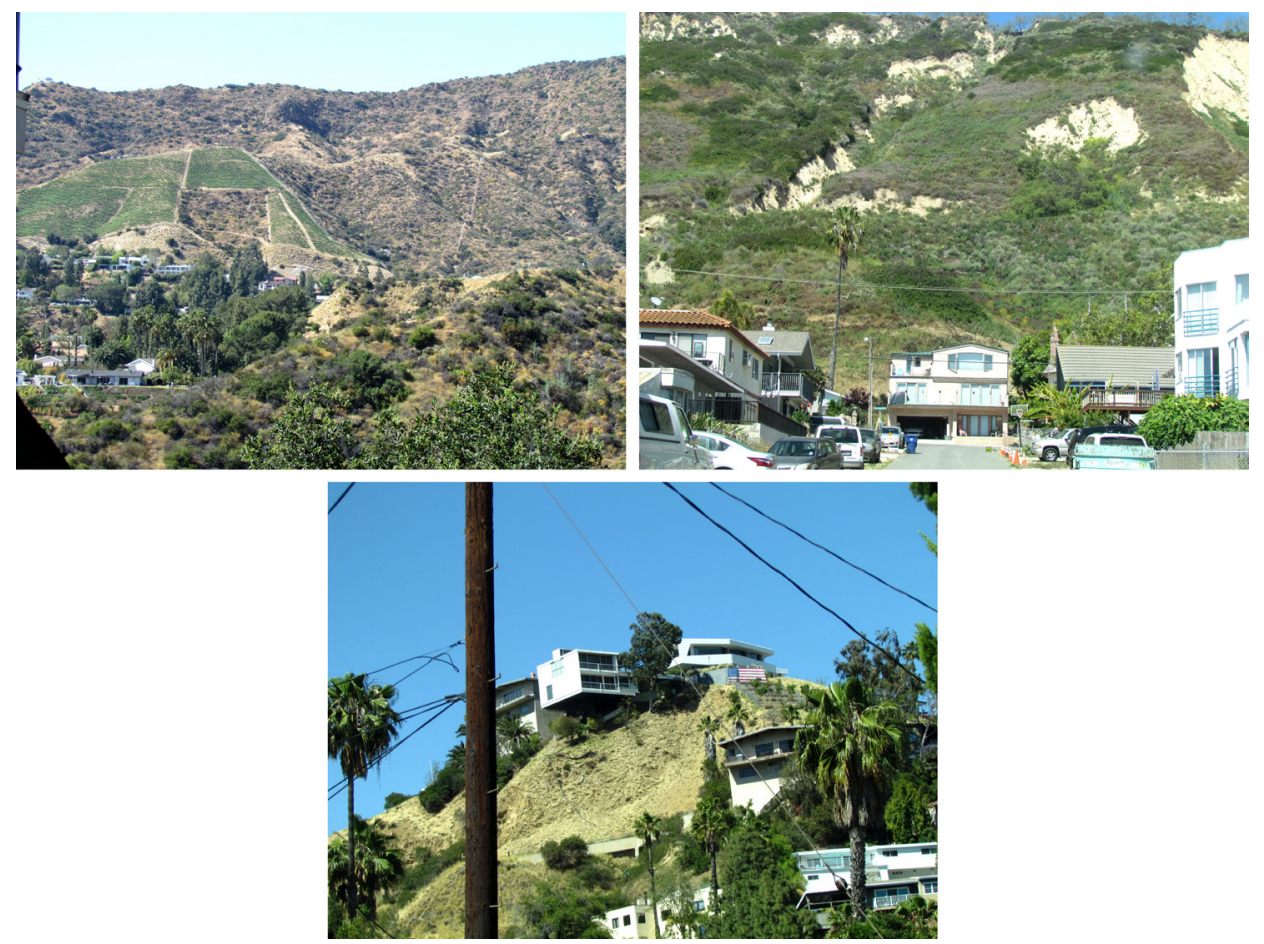

Figure 3 Figure 4 Figure 5 Fieldwork on May 2017

The economic development and urban expansion quickly filled the coastal plain of Los Angeles as well, leaving only the areas with greater slope for further expansion, increasing landslide risk to the population (McPhee, 1989; Soja, 2014).

To minimize the risk of populations vulnerable to landslides, during the 20th century, the main rivers - San Gabriel, Los Angeles and Tujinga - were channeled and damed to regulate the flow of water and debris, thereby minimizing the effects of gravitational movements. However, the construction of these dams was not enough to end the disasters caused by landslides, especially considering the catastrophic event described by McPhee (1989) that occurred in the San Gabriel Mountains and the massive debris flow in January, 2018.

In São Paulo the coastal plain land is narrow, which favored its rapid settlement and occupation of inappropriate areas, such as mangroves and hills with high slope (figures 6, 7 and 8). 
Saulo de Oliveira-Folharini, Regina Célia de-Oliveira. Estimate of housing and population in landslide risk areas in California (USA) and coastal São Paulo (Brazil)
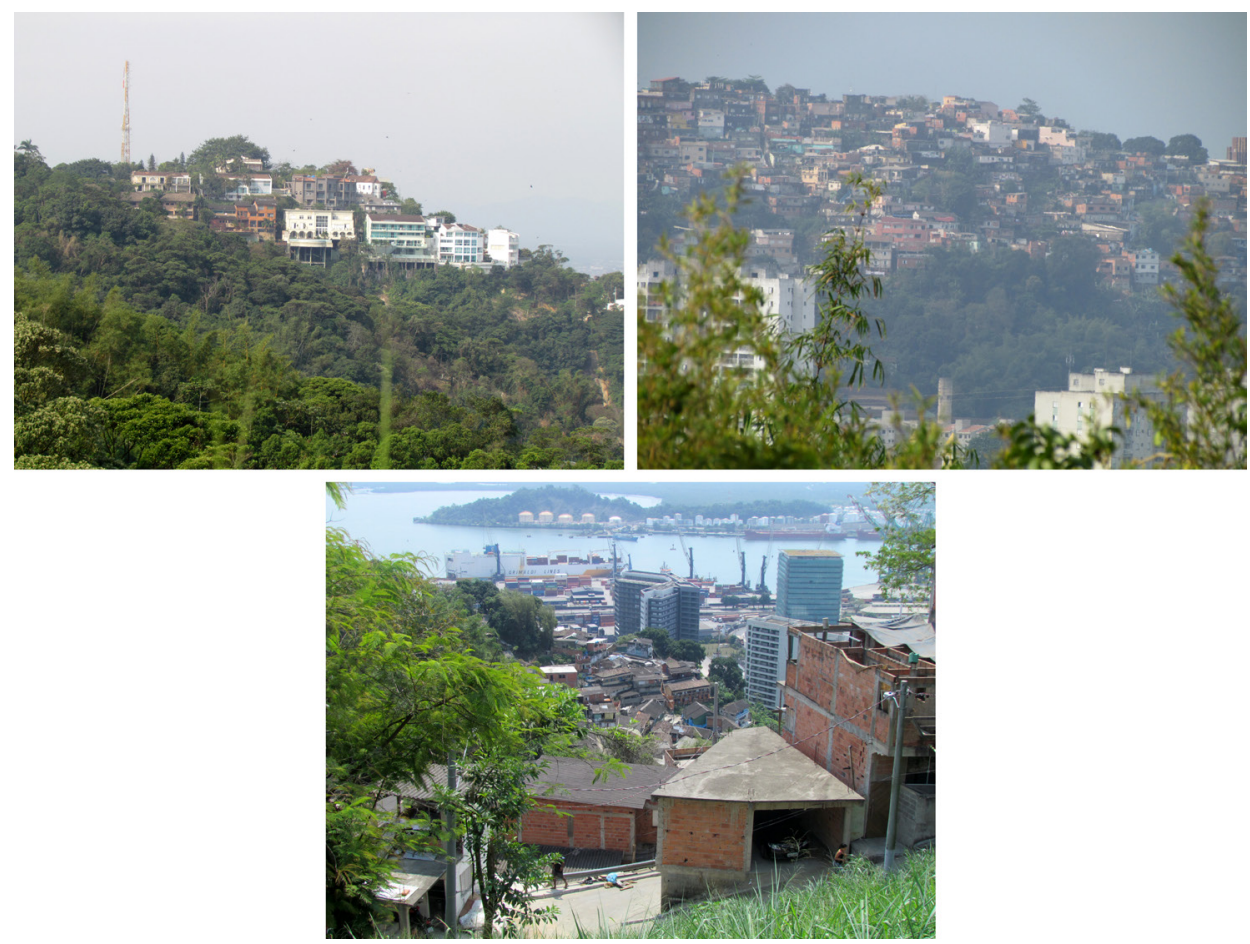

Figure 6 Figure 7 Figure 8 Fieldwork on September 2017

Those who have occupied these areas are poor, without means to pay for an apartment or house in the more expensive areas on the coastal plain. With the lack of adequate planning and regulations, settlement ended up favoring areas with slope above $30^{\circ}$. Studies conducted by Cruz (1974) and Marandola et al. (2013) note that these areas along the coast of the state of São Paulo are in a humid tropical climate zone with predominance of intense summer precipitation. Further development and the pushing of poor residents into inappropriate areas for housing will likely be impacted by state investments in infrastructure (expansion of the Tamoios highway and the port of São Sebastião), with the goal of increased tourism and the investments that come with that.

The figures 9 and 10 help us understand the land change use resulting from public policy and occupation of inappropriate areas. 
Saulo de Oliveira-Folharini, Regina Célia de-Oliveira. Estimativa de residências e população em áreas de risco a deslizamentos na costa da Califórnia (EUA) e São Paulo (Brasil)
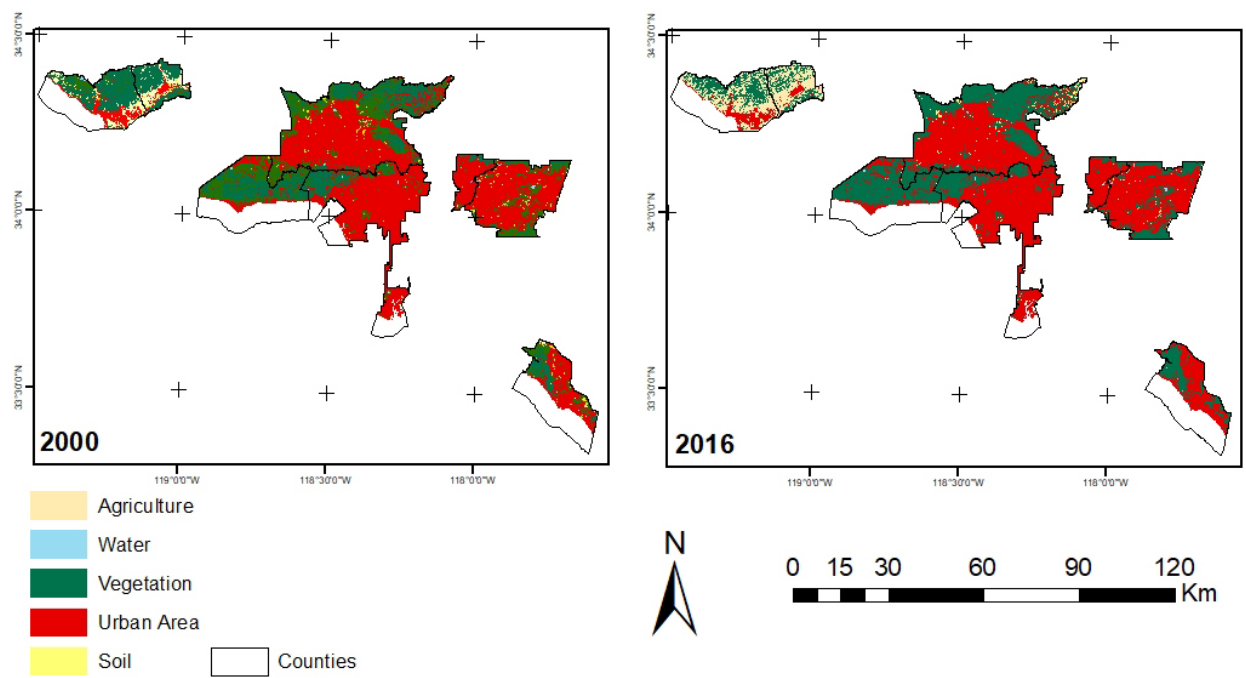

Figure 9: Classification results California. Organized by the author.

In coastal São Paulo the urban area increased by $1.25 \%$ during the study period. The population density was high due to investments in infrastructure, availability of job vacancies and the strong economy of the region.
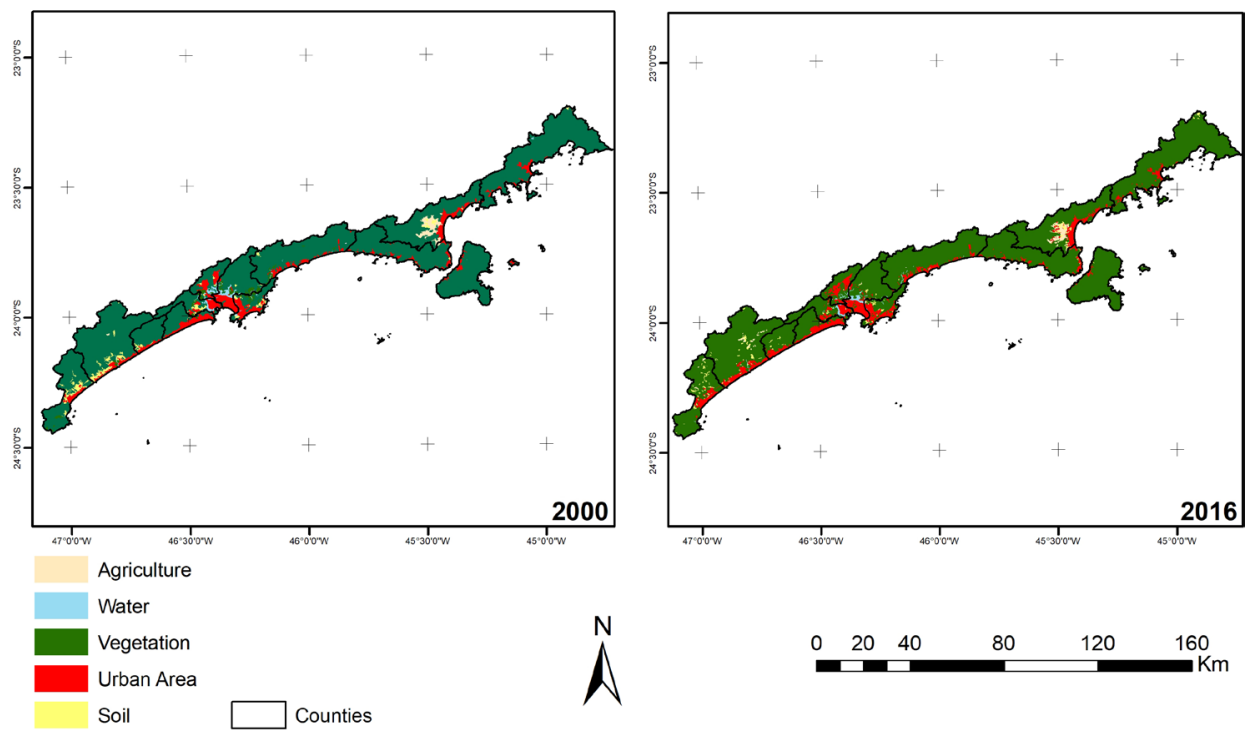

Figure 10: Classification results São Paulo. Organized by the author. 
Saulo de Oliveira-Folharini, Regina Célia de-Oliveira. Estimate of housing and population in landslide risk areas in California (USA) and coastal São Paulo (Brazil)

There was strong migration into the area, and consequently there was an increase in urban problems, such as lack of sanitation, vertical integration mainly on the waterfront, and in times of economic crisis, rising unemployment (Zündt, 2006).

The table II is the percentage of land change according to each class of mapping.

Table II: Percentage land change.

\begin{tabular}{|c|c|c|c|c|c|c|}
\hline \multicolumn{2}{|r|}{$N M$} & \multicolumn{5}{|c|}{2000} \\
\hline \multirow{9}{*}{ 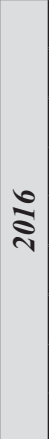 } & & Agriculture & Exposed Soil & Urban Area & Vegetation & Water \\
\hline & Agriculture & 76.746 & 11.457 & 0.863 & 10.042 & 0.488 \\
\hline & Exposed Soil & 2.244 & 17.060 & 0.886 & 0.821 & 3.581 \\
\hline & Urban Area & 8.426 & 53.906 & 94.746 & 6.383 & 20.805 \\
\hline & Vegetation & 12.559 & 17.376 & 3.460 & 82.710 & 7.806 \\
\hline & Water & 0.026 & 0.201 & 0.046 & 0.043 & 67.320 \\
\hline & Class Total & 100.000 & 100.000 & 100.000 & 100.000 & 100.000 \\
\hline & \begin{tabular}{|l} 
Class Changes \\
\end{tabular} & 23.254 & 82.940 & 5.254 & 17.290 & 32.680 \\
\hline & \begin{tabular}{|l|} 
Image Difference \\
\end{tabular} & 161.811 & -22.142 & 1.837 & -11.192 & -14.701 \\
\hline \multicolumn{2}{|r|}{ São Paulo } & \multicolumn{5}{|c|}{2000} \\
\hline \multirow{9}{*}{ 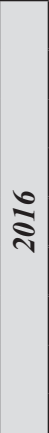 } & & Agriculture & Exposed Soil & Urban Area & Vegetation & Water \\
\hline & Agriculture & 52.995 & 2.772 & 0.308 & 0.376 & 0.186 \\
\hline & Exposed Soil & 14.326 & 18.083 & 0.647 & 0.759 & 0.046 \\
\hline & Urban Area & 20.168 & 48.705 & 86.009 & 1.353 & 9.382 \\
\hline & Vegetation & \begin{tabular}{|l|}
12.511 \\
\end{tabular} & 30.231 & 12.681 & 97.395 & 30.455 \\
\hline & Water & 0.000 & 0.210 & 0.355 & 0.118 & 59.930 \\
\hline & Class Total & 100.000 & 100.000 & 100.000 & 100.000 & 100.000 \\
\hline & Class Changes & 47.005 & 81.917 & 13.991 & 2.605 & 40.070 \\
\hline & Image Difference & -10.973 & -44.020 & 14.928 & 0.405 & -32.400 \\
\hline
\end{tabular}

The class with the most significant change in California is agriculture with an grew of $161.81 \%$ between 2000 and 2016, concentrated in Ventura County; the second most significant change was in urban area, which grew by $1.83 \%$, while the other classes decreased, demonstrating that anthropic use prevailed over the natural use. In addition, there is a transformation between exposed soil and urban area, demonstrating an increase in the occupation and previous replacement of vegetation areas by exposed soil. 
The increase of the urban area was small, but it was concentrated in the substitution of vegetation (3.46\%).

In São Paulo the principal change is a $14.92 \%$ increase of urban area and decrease of $44.02 \%$ of exposed soil and $10.97 \%$ of agriculture. The urban area is a principal class of change in relationship to agriculture (20.16\%) and exposed soil (48.70\%). The classification also shows a large increase of vegetation in the period, replacing respectively, $12.68 \%$ of urban area, $30.23 \%$ of exposure soil and $12.51 \%$ of agriculture.

This result indicates that there has been reforestation in coastal São Paulo, in spite of the increase in population.

In urban area change there was a $13.09 \%$ difference between California and coastal São Paulo, with the highest increase occurring in costal São Paulo (14.92\%) while the urban area in California increased only $1.83 \%$, indicating that urban expansion in coastal São Paulo is much larger than in coastal California. This increase in coastal São Paulo is related to infrastructure investment policies.

The second analysis involved interpolation to identify the concentration of areas with slope above $30^{\circ}$, using satellite images and a DEM. This indicated that urban occupation in the coastal plain is saturated, resulting in occupation of area with higher slopes and consequently increasing the population's vulnerability to disasters, such as landslides, mudslides and debris flows. Figures 11 and 12 indicate the areas in counties with slope above $30^{\circ}$ in California and São Paulo. 
Saulo de Oliveira-Folharini, Regina Célia de-Oliveira. Estimate of housing and population in landslide risk areas in California (USA) and coastal São Paulo (Brazil)
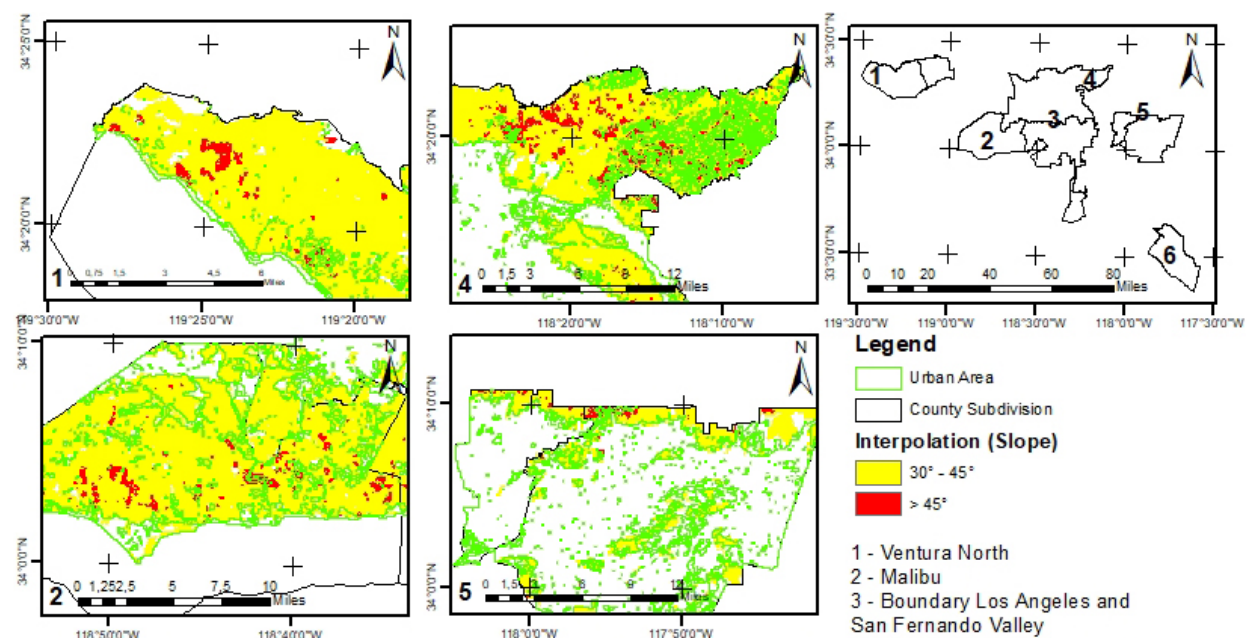

Legend

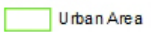

$\square$ County Subdivision

Interpolation (Slope)

$\square 30^{\circ}-45^{\circ}$

$>45^{\circ}$

1 - Ventura North

2 - Malibu

3 - Boundary Los Angeles and

San Fernando Valley
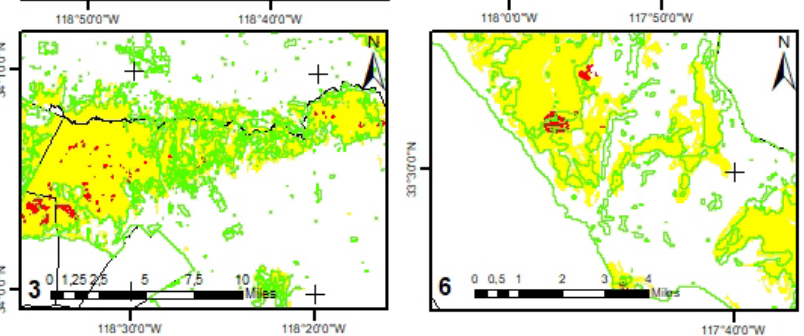

4 - San Fernando Valley North

5 - Upper and East San Gabriel Valley

6 - South Coast Center

Author. Saulo de Oliveira Folharini

Coordinate System: WGS 1984 UTM Zone $11 \mathrm{~N}$

Projection: Transverse M ercator

Datum: WGS 1984

False Easting: $500.000,0000$

False Northing: 0,0000

Central Meridian: $-117,0000$

Scale Factor: 0,9996

Latitude O f O rigin: 0,0000

Units: Meter

Figure 11: Areas of counties with concentration of slope above $30^{\circ}$

(California). Organized by the author. 

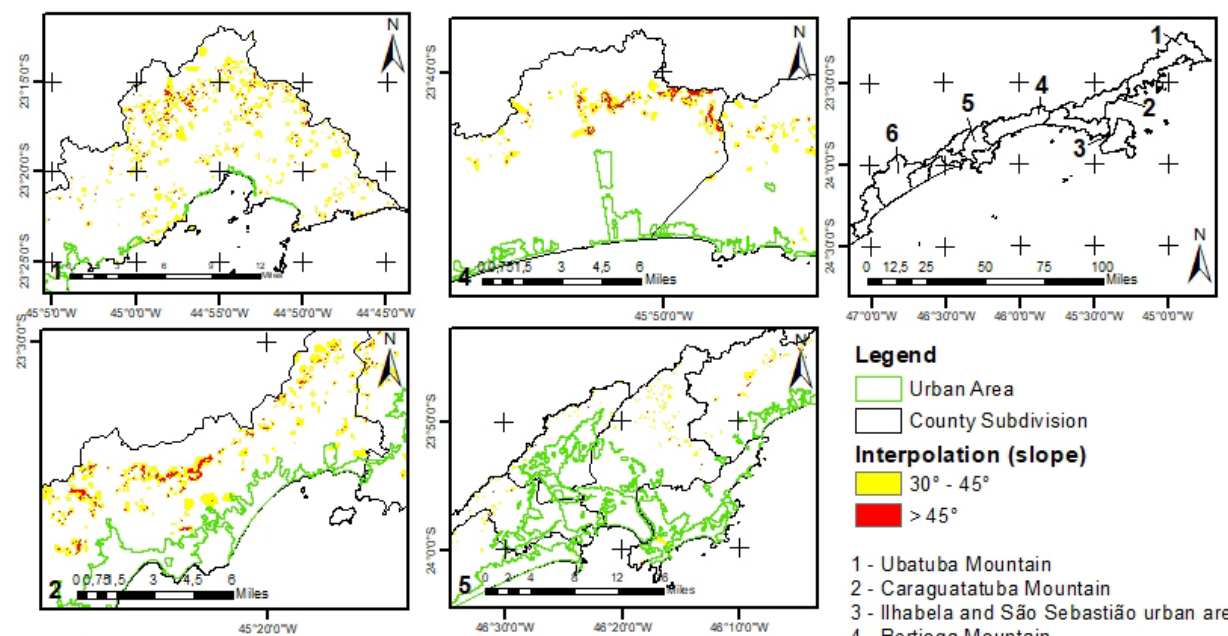

\section{Legend}

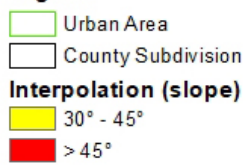

1 - Ubatuba Mountain

2 - Caraguatatuba Mountain

3 - Ilhabela and São Sebastião urban area

4 - Bertioga Mountain

5 - Baixada Santista urban area

6 - Itanhaém Mountain

Author. Saulo de Oliveira Folharini

Coordinate System: WGS 1984 UTM Zone 23S

Projection: Transverse $M$ ercator

Datum: WGS 1984

Falue Easting: $500.000,0000$

False Northing: $10.000 .000,0000$

Central M eridian: $-45,0000$

Scale F actor: 0,9996

Latitude O f O rigin: 0,0000

Units: Meter

Figure 12: Areas of counties with concentration of slope above $30^{\circ}$ (São Paulo). Organized by the author

The comparison of the areas in this step indicates that there is a greater concentration of urban area in areas with slope above $30^{\circ}$ in California. The concentration of urban areas with high demographic density, due to verticalization in areas of transition from the coastal plain to the higher Serra do Mar in São Paulo, exposed more people to landslides.

Another important point to note is that in California the occupation is concentrated in areas with slope above $30^{\circ}$, affecting the houses directly, and in São Paulo most of the occupation is along the margin of these areas. The coastal urban areas of São Paulo, however, are still affected by mudslides and debris transported from the the Serra do Mar to the coastal plain.

To complement the analysis of occupied areas with slope above $30^{\circ}$, we created a chart showing estimates of total housing and population of block groups in these areas (chart 1). 
Saulo de Oliveira-Folharini, Regina Célia de-Oliveira. Estimate of housing and population in landslide risk areas in California (USA) and coastal São Paulo (Brazil)

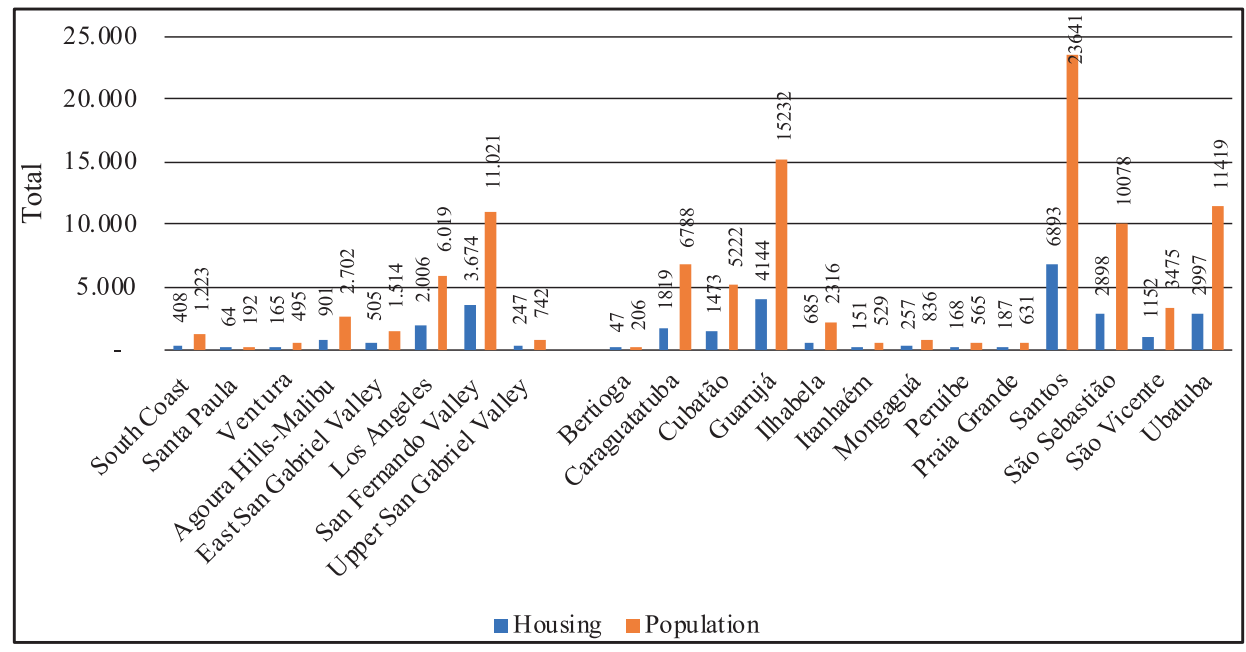

Chart 1: Estimate of Housing and Population in areas slope above $30^{\circ}$. Organized by the author.

These charts confirm that in California there was an expansion of urban area in San Fernando Valley in areas with slopes above $30^{\circ}$. This was the case as well in Los Angeles. The flat areas of the region are already completely occupied, and areas with slope above $30^{\circ}$ are also scenically beautiful and exclusive, so neighborhoods like the Hollywood Hills have seen a lot of urban development. In Upper and East San Gabriel Valley the occupation of areas of slope above $30^{\circ}$ was consolidated in the period analyzing, exponentially increasing the risk of population to landslides. In Agoura Hills-Malibu the population is concentrated along a narrow strip between the beach and the mountains. A landslide occurred here due to high precipitation and the intense settlement and increased tourism along Highway 01. Ventura and Santa Paula have specific neighborhoods with high risk for landslide, such as the historic landslides in La Conchita (Highland and Bobrowsky, 2008). In South Coast, occupation is concentrated in a narrow strip near the beach, with slopes lower than $30^{\circ}$. The urban area, however, is limited to the northeast with a relief characterized by closed valleys and vegetation sparse, favoring debris flows in periods of intense precipitation.

In coastal São Paulo, Santos, Cubatão, Guarujá and São Vicente counties have the largest number of people living in areas with slope above 
$30^{\circ}$. This area, called Baixada Santista, is the most economically important in the region, attracting large numbers of people to work in industries, such as steel manufacturing, and services related to the maritime transport sector. The construction of the Anchieta and Imigrantes highways helped in the transport of the production of the interior of the state and arrival of people to the coastal plain, making the economy thrive. In the North São Paulo Coast, Ubatuba, Caraguatatuba, São Sebastião and Ilhabela counties attracted a large population related to tourism, with the expansion of the second home market, occupying areas above slope $30^{\circ}$.

The Bertioga, Itanhaém, Mongaguá, Peruíbe and Praia Grande counties are areas of transition between the three sectors that make up the coast of São Paulo State. In these counties the urban area is concentrated in the plain, not occupying areas above slope $30^{\circ}$.

\section{Conclusion}

Capital ultimately plays an important role in the occupation of areas inappropriate for home construction. Capital's tendency to treat nature as something to be traded leads to real estate speculation, especially in coastal areas with scenic beauty. This scenario is quite prevalent in study area, with areas unfit for settlement occupied by mansions. This occupation is regulated by public agencies that provide basic infrastructure such as water and power, but public agencies are also responsible for rescuing the population in times of disasters, such as landslides. This demonstrates the power of the real estate sector over the power of a society to bring greater order to where individuals can construct homes.

For this reason, it is important for land use planners to have the information they need to bring about a more sensible occupation of available land, assuring residents have accees to the land they need, but without putting individuals at risk for disaster. To assist with land use planning, there are many types of remote sensing and georeferenced data that can be used and analyzed. In this paper satellite remote sensing was fundamental in providing information for a historical analysis of urban expansion in areas considered unfit for occupancy.

The conclusion is that occupation of inappropriate areas was quite variable, with an increase in areas of coastal California - San Fernando Valley and Los Angeles; in other counties the occupation was more

334 Revista Geográfica de América Central Nº 61E (3) Especial CLAG e-ISSN 2215-2563 • Julio-diciembre 2018 • pp. 319-337 
Saulo de Oliveira-Folharini, Regina Célia de-Oliveira. Estimate of housing and population in landslide risk areas in California (USA) and coastal São Paulo (Brazil)

consolidated already, especially in Upper and East San Gabriel Valley. In Ventura and Orange Counties the occupation occurred in areas susceptible to debris flows. The results from Coastal São Paulo, in general, showed recomposition of native vegetation, but the high population density places the Brazilian counties at much greater exposure to the risk of landslides. Greater efforts in land use planning in the coastal area of the state of São Paulo would have the possibility of reducing the risk of the population exposed to the landslides and ensuring that housing occurs only in the most adequate areas for settlement.

\section{Acknowledgement}

This research was supported by Brazilian Federal Agency for Support and Evaluation of Graduate Education, process $n^{\circ} 88881.133719 / 2016-$ 01, Doctoral Stay Program. The first author thanks Environmental Studies Program at The University of Kansas and Prof. Dr. J. Christopher Brown for receiving him in $\mathrm{PhD}$ exchange abroad.

\section{Bibliography}

Ab’Saber, A. A. (1987). A Serra do Mar na região de Cubatão: avalanches de janeiro de 1985. In: Simpósio Da Costa Sul e Sudeste Brasileira. Síntese Dos Conhecimentos. Cananéia, ACIESP - Academia de Ciências Do Estado de São Paulo, 74-116.

Biasutti, M., Seager, R. and Kirschbaum, D. B. (2016). Landslides in West Coast metropolitan areas: The role of extreme weather events. Weather and Climate Extremes, (14), 67-79. https://doi. org/10.1016/j.wace.2016.11.004

Bitar, O. Y., Freitas, C. G. L. and Ferreira, A. L. (2012). Classificação da declividade para fins de normalização geotécnica em planejamento urbano: estudos em áreas de domínio pré-cambriano na região sudeste. $46^{\circ}$ Congresso Brasileiro de Geologia, 1 Congresso de Geologia de Países de Língua Portuguesa. Santos-SP.

Bonachea, J., Bruschi, V. M., Hurtado, M. A., Forte, L. M., Silva, M. da, Etcheverry, R., Cendrero, A. (2010). Natural and human forcing in recent geomorphic change; case studies in the Rio de la Plata basin. Science of the Total Environment, (408), 2674-2695. 
Cortes, C., \& Vapnik, V. (1995). Support-Vector Networks. Machine Learning, (20), 273-297. Retrieved from http://image.diku.dk/imagecanon/material/cortes_vapnik95.pdf

Cruz, O. (1974). A Serra do Mar e o litoral na área de Caraguatatuba-SP: contribuição à geomorfologia litorânea tropical. São Paulo. Universidade de São Paulo. Instituto de Geografia, 181 p.

Dai, F. and Lee, C. . (2002). Landslide characteristics and slope instability modeling using GIS, Lantau Island, Hong Kong. Geomorphology, 42 (3-4), 213-228. https://doi.org/10.1016/S0169-555X(01)00087-3

Galparsoro, L. U. and Fernández, S. P. (2001). Medidas de concordancia: el índice Kappa. Unidad de Epidemiología Clínica y Bioestadística. Complexo Hospitalario-Universitario Juan Canalejo. A Coruña (España). Retrieved from http://www.fisterra.com/mbe/investiga/ kappa/kappa.htm

Goldberg, S. (2006). Falling into the Pacific: Califórnia landslides and land use controls, Southern California Review of Law and Social Justice, Volume 16, Number 1, Fall 2006, 95.

Highland, L. M. and Bobrowsky, P. (2008). The landslide handbook - A guide to understanding landslides: Reston, Virginia, U.S. Geological Survey Circular 1325, 129 p.

Huang, C., Davis, L. S. and Townshend, J. R. G. (2002). An assessment of support vector machines for land cover classification. International Journal of Remote Sensing, (23), 725-749.

Marandola, E., Marques, C., Paula, L. T. and Cassaneli, L. B. (2013). Crescimento urbano e áreas de risco no litoral norte de São Paulo. Revista Brasileira de Estudos Populacionais, 30(1), 35-56.

McPhee, J. (1989). The control of nature. New York, United States of American: Farrar, Straus \& Giroux.

Miller, C. S. and Hyslop, R. S. (2000). Califórnia. The geography of diversity. Los Angeles, United States of American: Mayfield Publishing Company.

Moraes, A. C. R. (2007). Contribuições para a gestão da zona costeira do Brasil: elementos para uma geografia do litoral brasileiro. São Paulo, Brasil: Annablume.

Robbins, P. (2012). Political ecology: a critical introduction (2nd ed). Sussex, United Kington: Wiley-Blackwell. 
Saulo de Oliveira-Folharini, Regina Célia de-Oliveira. Estimate of housing and population in landslide risk areas in California (USA) and coastal São Paulo (Brazil)

Smith, K. (2004). Environmental hazards: assessing risk and reducing disaster (4th ed.). New York, United State: Taylor \& Francis.

Soja, E. W. (2014). My Los Angeles: from urban restructuring to regional urbanization. Los Angeles: University of California Press. Berkeley Los Angeles London.

Steinwart, I., \& Christmann, A. (2008). Support Vector Machines. University of California, Berkeley, United State: Springer. Retrieved from http://www.springer.com/la/book/9780387772417

TATIZANA, C., OGURA, A. T., CERRI, L. E. D. S., \& ROCHA, M. C. . (1987). Análise da correlação entre chuvas e escorregamentos aplicados às encostas da Serra do Mar, município de Cubatão. Congresso Brasileiro de Geologia de Engenharia, 5, 1987, São Paulo. Anais , São Paulo: ABGE. v.2, p.225-236.

Wills, C. J., Perez, F. G., \& Gutierrez, C. I. (2011). Susceptibility to deep-seated landslides in California. Map Sheet 58. Los Angeles, United State: California Geological Survey Retrieved from http://www.conservation. ca.gov/cgs/information/publications/ms/Documents/MS58.pdf

Zündt, C. (2006). Baixada Santista: uso, expansão e ocupação do solo, estruturação de rede urbana regional e metropolização. In J. M. P. Cunha (Ed.), Novas metrópoles paulistas: população, vulnerabilidade e segregação (pp. 305-336). Campinas: Núcleo de Estudos de População, Universidade Estadual de Campinas. Retrieved from http://www.nepo.unicamp.br/publicacoes/livros/vulnerabilidade/arquuivos/arquuivos/vulnerab_cap_11_pgs_305_336.pdf 
